American Journal of Primatology 38:315-332 (1996)

\title{
Number of Males in Primate Groups: Comparative Tests of Competing Hypotheses
}

\author{
JOHN C. MITANI, JULIE GROS-LOUIS, AND JOSEPH H. MANSON \\ Department of Anthropology, University of Michigan, Ann Arbor
}

Primate social groups frequently contain multiple males. Male group size has been hypothesized to result from male mating competition, but the selective factors responsible for the evolution of multimale groups are unclear. Short breeding seasons create situations that are not conducive for single males to monopolize mating access to females, and may therefore favor the formation of large male groups. Alternatively, since the costs of mate defense increase with the spatial clumping of females, female group size may be a primary determinant of the number of males in a primate group. We used comparative methods designed to control for the potentially confounding effects of hidden third variables associated with phylogeny to test the breeding season and female group size hypotheses for the evolution of multimale groups. Our results revealed no association between breeding season duration and the number of males in groups. In contrast, we provide support for the female group size hypothesis by demonstrating a strong pattern of correlated evolution between female and male group size. (c) 1996 Wiley-Liss, Inc.

Key words: primate behavioral ecology, animal sociality, comparative methods

\section{INTRODUCTION}

One hallmark of the order Primates is a near-universal pattern of sociality. Virtually all species of monkeys and apes live in relatively stable social groups, many of which consist of multiple males and females [reviews in Smuts et al., 1987]. The unusual gregariousness of primates has led several investigators to examine the selective factors responsible for group living [Crook, 1970; Wrangham, 1980, 1987; van Schaik, 1983, 1989; Terborgh \& Janson, 1986; Isbell, 1990; Janson, 1992]. In contrast, a second but related question concerning the characteristic composition of groups has received less attention. Why do primates live in groups that contain several males?

Previous research sought ecological factors that might account for the multimale group structure observed in many primate species, but readily identifiable ecological correlates remain obscure [Eisenberg et al., 1972; Clutton-Brock \&

Received for publication January 30, 1995; revision accepted August 30, 1995.

Address reprint requests to John Mitani, Department of Anthropology, University of Michigan, Ann Arbor, MI 48109.

(c) 1996 Wiley-Liss, Inc. 


\section{6 / Mitani et al.}

Harvey, 1976]. Recently, Ridley [1986] and Altmann [1990] have invoked sexual selection theory to explain the distribution of males in primate groups. Ridley [1986] proposed that multimale groups are more common in species with short breeding seasons. In these animals, females come into estrus in rapid succession during relatively brief periods, thus making it difficult for single males to monopolize mating access to them [cf. Trivers, 1972; Berenstain \& Wade, 1983]. In contrast, several other researchers have suggested that the spatial distribution of females may be a better predictor of the number of males in primate groups [Terborgh, 1983; Andelman, 1986; Dunbar, 1988; Altmann, 1990; Janson, 1992]. Because of their greater investment in offspring, females are a limiting resource for male reproduction in most primates [Trivers, 1972]. One consequence of this asymmetry in parental investment is that different factors will regulate the reproduction of females and males; while females are generally limited by their access to food resources, males are typically constrained by the availability of fertile females. Viewed within this context, variations in animal societies can be understood in terms of the interaction between female social dispersion and male mating tactics, with males adjusting themselves to the spatial distributions of females [Bradbury \& Vehrencamp, 1977; Emlen \& Oring, 1977; Wrangham, 1980; CluttonBrock, 1989]. This reasoning led Altmann [1990] to propose that the number of males found in a group is ultimately controlled by the number of females, i.e., "primate males go where the females are" [cf. Terborgh, 1983; Andelman, 1986; Dunbar, 1988; Janson, 1992].

In this paper, we provide comparative tests of the two hypotheses outlined above to explain the evolution of multimale-multifemale groups in primates. First, we present mutually exclusive predictions generated by each hypothesis and examine the extent to which reconstructed evolutionary changes in breeding season durations and group sizes are consistent with these predictions. Results of this test remain inconclusive due to small samples. Second, we use two recently developed comparative techniques to examine the pattern of correlated evolution between the number of males in groups and (1) breeding season durations and (2) female group sizes [Felsenstein, 1985; Maddison, 1990]. Our results are consistent with the hypothesis that female grouping determines the observed patterns of male social dispersion.

\section{METHODS}

\section{Selection of Field Studies}

The preceding hypotheses apply to primates living in nonmonogamously mating groups. We limited our analyses to those species that have published figures for the relevant independent and dependent variables. Only observations made during long-term field research of known individuals were included. Where the same species has been observed at different sites, we gave preference to those studies that covered the longest period and greatest number of groups or had reported all the variables of interest.

\section{Variables}

The following tests require estimates of breeding season durations and the numbers of females and males in groups. Following Ridley [1986], we used observations of birth seasonality to infer the duration of the effective mating season. Female primates are well known for copulating outside their fertile periods [e.g., Hrdy \& Whitten, 1987], and we assume the birth season to be a better indicator of mating resulting in reproduction rather than the mating season alone. We used Ridley's [1986] criterion of $75 \%$ of all births to define breeding seasons. 
TABLE I. The Number of Males in Primate Groups*

\begin{tabular}{lcc}
\hline & \multicolumn{2}{c}{ Hypotheses } \\
\cline { 2 - 3 } & Mating season duration & Female group size \\
\hline Small female group size, short breeding season & Multimale & Single male \\
Large female group size, long breeding season & Single male & Multimale \\
\hline
\end{tabular}

*Mutually exclusive predictions regarding the relationships between the number of males in groups and (1) mating season durations and (2) female group sizes. Predictions are derived from single-factor hypotheses to explain the distribution of males in primate groups. See text for further explanation.

Estimating modal group sizes and compositions for individual species is difficult. The problem is exacerbated in cases where there is substantial intraspecific variability in these parameters. To deal with these problems, we developed an explicit set of rules to define these variables. We used median values for each species to determine the numbers of females and males in groups. We calculated individual group values for species in which one group was observed during a single period. In cases where a single group was studied over multiple years, we employed the medians of annual counts. We computed medians of groups for species in which multiple groups were followed during a single period. Finally, in situations where multiple groups were observed during several years, we first calculated the median of each group across years and then obtained the median of these group values. Species in which mating season mobility by males has been reported [e.g., Cords, 1984; Tsingalia \& Rowell, 1984; Chism \& Rowell, 1986; Cords et al., 1986; Struhsaker, 1988] present a special problem in the computation of the number of males in a group. Such mobility does not occur during every mating season or in all groups (Cords, personal communication), and we therefore computed median values in the manners described above for studies in which data existed. Using these criteria, we classified red-tail monkeys (Cercopithecus ascanius) and blue monkeys (Cercopithecus mitis) as "single male." Since debate continues over the validity of such a classification [e.g., Rowell 1988], we performed additional tests in which both species were categorized as "multimale." For this latter classification, we used the mean number of males per group provided by Cords and colleagues for red-tail [6.4; Cords, 1984] and blue monkeys [5.9; Cords et al., 1986].

\section{The Tests}

The preceding hypotheses generate mutually exclusive predictions regarding how male social dispersion will vary as a function of breeding season duration and female group size in nonmonogamously mating species (see Table I). Specifically, the breeding season hypothesis predicts that multimale groups will be found in those species that show short breeding seasons irrespective of whether female groups are large or small. In contrast, the female group size hypothesis predicts that multiple males will occur in groups with large numbers of females independent of whether breeding seasons are long or short. As a result, species that show short breeding seasons with small female groups or long breeding seasons with large female groups provide the critical test cases for the two hypotheses (Table I). In the following analyses, we lump nonseasonal breeders which mate throughout the year into the category of species who show "long" mating seasons. Thus, we contrast species which breed during relatively short seasons with those which mate over relatively long periods or nonseasonally.

Evaluating these predictions required that we assign species into two catego- 


\section{8 / Mitani et al.}

ries for each independent variable. We determined these categories empirically by examining the distributions of female group sizes and breeding season durations. We excluded species that mate throughout the year in the latter calculations; inclusion of year-round breeders would inflate the cut-off point, thus creating "short" breeding seasons that are in fact extremely long [cf. Ridley, 1986]. Each variable was non-normally distributed (Kolmogorov-Smirnov tests, two-tailed $P$ $<<0.001$ for both comparisons), with female group size showing an extreme skew toward the right. Given these observed distributions, we employed the median values of each independent variable to distinguish short and long breeding seasons and small and large female groups. Using these criteria, breeding seasons were considered short if they were less than or equal to the median value of approximately 3 months (92 days). Seven or fewer females constituted small groups.

Traditional comparative analyses of primate behavior utilize species or genera as independent data points [e.g., Crook \& Gartlan, 1966; Clutton-Brock et al., 1977; Harcourt et al., 1981]. Species and genera share characteristics due to common ancestry, however, and cannot be considered independent [Harvey \& Pagel, 1991]. Traditional procedures thus artificially inflate sample sizes and the degrees of freedom used in statistical tests. To control the potentially confounding effects introduced by phylogeny, we conducted an analysis based on independent evolutionary events. Here we tallied the number of species that fit into each of the categories of (1) small female groups showing short breeding seasons and (2) large female groups with long breeding seasons (Table I). To ensure phylogenetic and statistical independence, we counted only those past or present lineages that had shown an unambiguous transition in breeding season duration or female group size based on phylogenetic reconstructions of these characters. For these reconstructions (see below), we employed the Fitch [1971] optimization algorithm as implemented in MacClade [version 3.04, Maddison \& Maddison, 1992]. This procedure assumes that our characters, breeding season duration and female group size, are unordered. Thus, a change from any state to another could occur in a single step, e.g., small female groups were permitted to transform into large female groups and vice versa.

We employed Felsenstein's [1985] pairwise comparison method as a second means to control for the possible effects of phylogeny [see also Burt, 1989]. Here we computed the average number of males per group in matched sets of species that differed in the independent variable of interest. Sets were constructed by matching taxa with long breeding seasons to the most closely related taxa displaying short breeding seasons. We also matched taxa with large female groups to those exhibiting small female groups. To ensure independence, pairs were not allowed to share a taxon or phylogenetic branch at any level. By using only extant species in forming pairs [Møller \& Birkhead, 1992; Oakes, 1992], we circumvented the inherent problems associated with reconstructing behavioral states of ancestral species [Maddison \& Maddison, 1992]. We compared the numbers of males per group in taxa that differed in breeding season duration and female group size using a Wilcoxon matched-pairs, signed-ranks test [Siegel \& Castellan, 1988].

Felsenstein's test can be used to examine associations between variables, but does not account for the direction of change between them, i.e., does not isolate dependent from independent variables. We subsequently employed Maddison's [1990] concentrated changes test to investigate the effects of breeding season duration and female group size on the number of males found in primate groups. This test determines whether a change in a dependent variable, e.g., male group structure, occurs more often than expected by chance on branches of a phylogeny with a specified state in a second, independent variable, e.g., long or short breeding 
season. Probability values are computed through simulations in which changes in the dependent variable are randomly distributed on all branches of the phylogeny. An observed concentration of changes in areas of the phylogeny distinguished by the specified state of the independent variable leads to rejection of the null hypothesis of no association.

Maddison's test does not permit the use of polytomies on a phylogenetic tree, i.e., cases with two or more descendants from a single node (e.g., Cebus genera, Fig. 1a). To implement Maddison's test, we excluded situations involving these unresolved relationships by deleting taxa using a random numbers table. We conducted 10,000 simulations in which the observed number of gains and losses of multimale group structure was randomly distributed on clades displaying character states of the two independent variables. These simulations were used to generate the probability distributions of the observed gains and losses in multimale group structure given the phylogenetic distributions of short and long breeding seasons and small and large female group sizes. For purposes of these analyses a gain is defined as a transition from a single-male to multimale group, while a loss constitutes a transition from a multimale to single-male group. We adopted the conservative procedure of examining only actual and unambiguous changes in character states, excluding those that were estimated through reconstructions.

\section{Phylogenetic Reconstructions}

Felsenstein's [1985] and Maddison's [1990] comparative techniques depend on ascertaining phylogenetic relationships among organisms. Producing a consensus reconstruction presented an additional problem insofar as relationships among primate species remain contentious [Cartmill \& Yoder, 1994]. Here again, we followed a conservative procedure by constructing two alternative trees, one based on traditional neontological and paleontological data, the other derived from molecular evolutionary studies. While both trees correspond to each other reasonably well, they differ in details (Fig. 1a,b). As a result, we duplicated all of the following tests on both trees. The internal consistency of the neontological-paleontological tree was not high, especially for some New and Old World monkeys, and as a result we conducted an additional test in which the relationships of these taxa differed (Fig. 1c). This procedure permitted us to evaluate the sensitivity of our tests to alterations in the phylogenetic relationships of the species used in the analysis.

\section{RESULTS}

Table II shows our compilation of data for each of the variables, while Figure 1 illustrates the phylogenetic trees used in the following analyses. Figure 2 reveals that four unambiguous changes in either breeding season duration or female group size can be assigned to our reconstruction based on the neontological-paleontological data. Only two of these changes, one in the common ancestor of chimpanzees and gorillas, the other in Colobus badius, bear on our set of predictions (Table I). These two changes are consistent with the hypothesis that small fernale group size limits the number of males in a primate group (Table III), but provide only very weak support. Analyses using the molecular phylogeny (Fig. 1b) and alternate neontological-paleontological tree (Fig. 1c) yielded similar and equally inconclusive results. Reclassification of the two Cercopithecus species (see above) as multimale does not affect any of these results.

We employed Felsenstein's pairwise comparison method to examine the associations between male social dispersion and breeding season duration and female group size. Figure 3 shows the distribution of the two independent variables on our neontological-paleontological tree. Figure 4 summarizes the results of a matched- 
a.

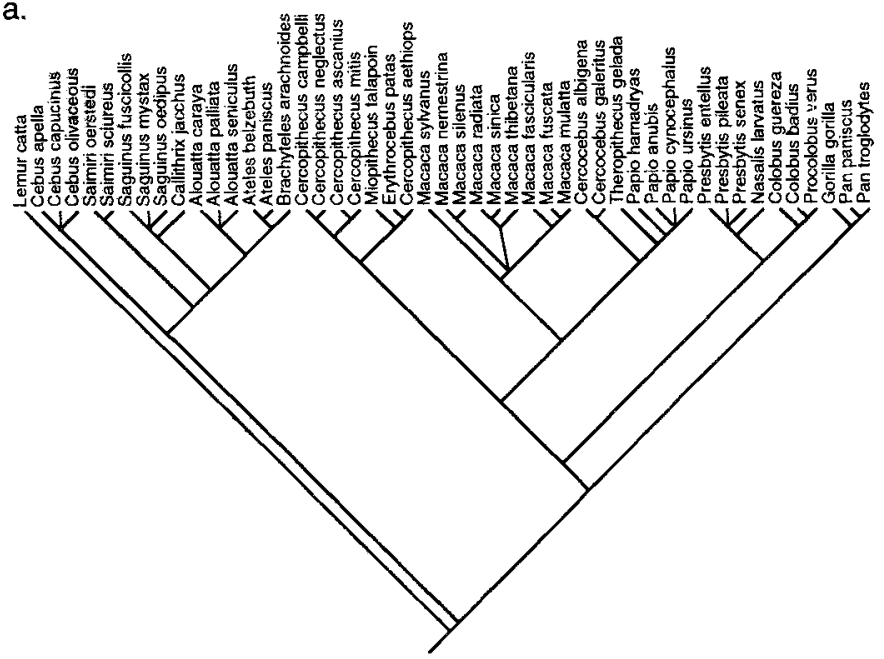

b.

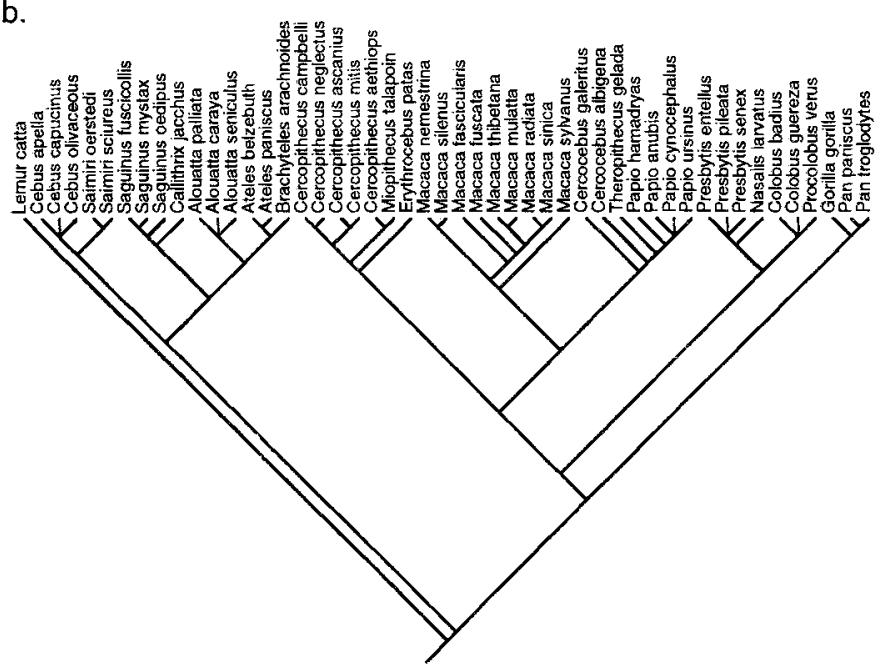

c.

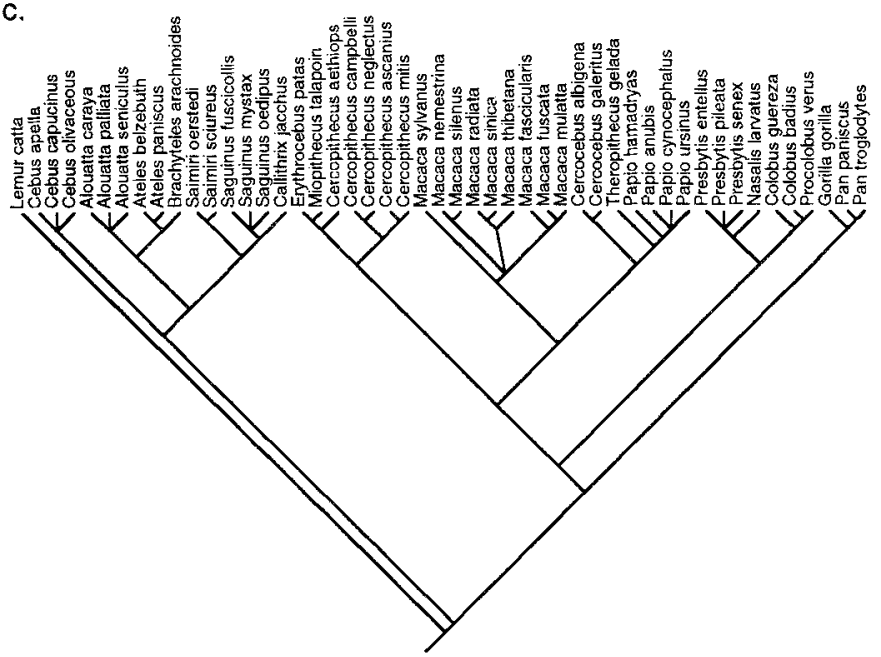

Fig. 1. Alternative primate phylogenies. a: A neontological-paleontological phylogeny based on: Ford [1986] for New World monkeys; Delson [1980] for macaques; Strasser and Delson [1987] and Gautier [1988] for the African cercopithecines; Oates et al. [1994] for colobines; and McHenry [1984] for the African apes. b: A molecular phylogeny based on: Cronin and Sarich [1975, 1978] for New World monkeys; Cronin et al. [1980] and Melnick et al. [1993] for macaques; Ruvolo [1988] for African cercopithecines; and Ruvolo et al. [1994] for the African apes. c: An alternative neontological-paleontological phylogeny based on Kay [1990] for the New World monkeys and Martin and MacLarnon [1988] for the African cercopithecines. Other lineages in c depicted as in a. 
TABLE II. Estimates of Breeding Season Durations, Female Group Size, and Male Group Size in Primates.*

\begin{tabular}{|c|c|c|c|c|}
\hline Species & $\begin{array}{c}\text { Breeding season } \\
\text { duration (days) }\end{array}$ & $\begin{array}{l}\text { Female } \\
\text { group size }\end{array}$ & $\begin{array}{c}\text { Male group } \\
\text { size }\end{array}$ & References $^{1}$ \\
\hline Lemur catta & 38 & 4 & 4.5 & 1,2 \\
\hline Callithrix jacchus & 365 & 2 & 2 & 3,4 \\
\hline Saguinus fuscicollis & 151 & 1 & 1.88 & 5,6 \\
\hline Saguinus mystax & 153 & 2 & 2 & 7 \\
\hline Saguinus oedipus & 122 & 1 & 2 & 8,9 \\
\hline Alouatta caraya & 365 & 2 & 1 & 10 \\
\hline Alouatta palliata & 365 & 8 & 3 & 11,12 \\
\hline Alouatta seniculus & 365 & 2.5 & 1.5 & 13,14 \\
\hline Ateles belzebuth & 365 & 11.5 & 4 & 15,16 \\
\hline Ateles paniscus & 365 & 15.5 & 5 & 17 \\
\hline Brachyteles arachnoides & 153 & 9 & 7 & 18,19 \\
\hline Cebus apella & 92 & 2.25 & 2 & 20,21 \\
\hline Cebus capucinus & 212 & 4 & 5.5 & 22,23 \\
\hline Cebus olivaceous & 124 & 6 & 1 & 24 \\
\hline Saimiri oerstedi & 59 & 16 & 10 & 25,26 \\
\hline Saimiri sciureus & 61 & 23 & 7 & 27 \\
\hline Colobus badius & 244 & 9.5 & 3.5 & 28,29 \\
\hline Colobus guereza & 365 & 3 & 1 & 30,31 \\
\hline Procolobus verus & 89 & 2 & 1.25 & 32,33 \\
\hline Nasalis larvatus & 62 & 5 & 1 & 34,35 \\
\hline Presbytis entellus & 365 & 12 & 1 & 36,37 \\
\hline Presbytis pileata & 120 & 4 & 1 & 38,39 \\
\hline Presbytis senex & 153 & 5 & 1 & 40,41 \\
\hline Cercocebus albigena & 212 & 6 & 3 & 42,43 \\
\hline Cercocebus galeritus & 59 & 6 & 2 & 44,45 \\
\hline Cercopithecus aethiops & 92 & 4.25 & 3 & 46,47 \\
\hline Cercopithecus ascanius & 182 & 9.5 & 1 & 48 \\
\hline Cercopithecus campbelli & 62 & 4 & 1 & 49 \\
\hline Cercopithecus mitis & 120 & 18 & 1 & 50,51 \\
\hline Cercopithecus neglectus & 90 & 3 & 1 & 52,53 \\
\hline Miopithecus talapoin & 59 & 27 & 13 & 54 \\
\hline Erythrocebus patas & 62 & 12.5 & 3 & 55 \\
\hline Macaca fascicularis & 123 & 6.75 & 4 & 56,57 \\
\hline Macaca fuscata & 46 & 9 & 3 & $58,59,60$ \\
\hline Macaca mulatta & 82 & 9 & 2.5 & 61 \\
\hline Macaca nemestrina & 365 & 22 & 3 & 62,63 \\
\hline Macaca radiata & 92 & 9 & 7 & 64 \\
\hline Macaca silenus & 365 & 7 & 1.75 & 65,66 \\
\hline Macaca sinica & 66 & 9.5 & 5 & 67,68 \\
\hline Macaca sylvanus & 76 & 10.5 & 9 & 69,70 \\
\hline Macaca thibetana & 89 & 9.5 & 4.5 & 71,72 \\
\hline Papio anubis & 365 & 34 & 14 & 73,74 \\
\hline Papio cynocephalus & 365 & 13 & 8 & $75,76,77$ \\
\hline Papio hamadryas & 365 & 2 & 1 & 78,79 \\
\hline Papio ursinus & 365 & 14.5 & 7 & 80 \\
\hline Theropithecus gelada & 365 & 4 & 1 & 81,82 \\
\hline Gorilla beringei & 365 & 3 & 1 & 83,84 \\
\hline Pan paniscus & 365 & 8 & 8 & 85 \\
\hline Pan troglodytes & 365 & 35 & 10 & 86 \\
\hline
\end{tabular}

*See text for further explanation.

${ }^{1}$ References: (1) Sauther, 1991; (2) Sussman, 1991; (3) Digby and Barreto, 1993; (4) Digby and Ferrari, 1994; (5) Goldizen et al., 1988; (6) Goldizen, 1989; (7) Garber et al., 1993; (8) Dawson and Dukelow, 1976; (9) Dawson, 1978; (10) Rumiz, 1990; (11) Clarke and Glander, 1984; (12) Glander, 1980; (13) Crockett and Rudran, 1987; (14) Rudran, 1979; (15) Klein, 1971; (16) Klein and Klein, 1976; (17) Symington, 1988; (18) Strier and Ziegler, 1994; (19) Strier et al., 1993; (20) Janson, 1984; (21) Janson, 1988; (22) Fedigan and Rose, personal communication (23) Fedigan, 1993; (24) Robinson, 1988; (25) Boinski, 1987a; (26) Boinski, 1987b; (27) Mitchell, 1990; (28) Struhsaker and Leland, 1987; (29) Struhsaker, 1975; (30) Oates, unpublished, in Struhsaker and Leland, 1987; (31) Oates, 1977; (32) Oates, personal communication; (33) Oates, 1994; (34) Yeager, personal communication; (35) Yeager, 1990; (36) Sommer and Rajpurohit, 1989; (37) Borries et al., 1991; (38) Stanford, 1991a; (39) Stanford, 1991b; (40) Rudran, 1973a; (41) Rudran, 1973b; (42) Waser, personal communication; (43) Waser, 1975 (44) Homewood, 1976; (45) Kinnaird and O'Brien, 1991; (46) Cheney et al., 1988; (47) Cheney and Seyfarth, 1987; (48) Struhsaker, 1988; (49) Bourlière et al., 1969; (50) Cords, personal communication; (51) Tsingalia and Rowell, 1984; (52) Wahome, personal communication; (53) Wahome et al., 1993; (54) Gautier-Hion, 1970; (55) Chism and Rowell, 1986; (56) van Schaik and van Noordwijk, 1985; (57) van Noordwijk, 1985; (58) Takahata et al., in press; (59) Sprague, personal communication; (60) Maruhashi, 1982; (61) Lindburg, 1971; (62) Caldecott, 1986; (63) Oi, 1990; (64) Sugiyama, 1971; (65) Kumar and Kurup, 1985; (66) Kurup and Kumar, 1993; (67) Dittus, personal communication; (68) Dittus, 1977; (69) Ménard and Vallet, 1993; (70) Ménard et al., 1985; (71) Zhao and Deng, 1988a; (72) Zhao and Deng, 1988b; (73) Nicolson, 1982; (74) Smuts, 1985; (75) Altmann et al., 1988; (76) Altmann, personal communication; (77) Altmann et al., 1985; (78) Stammbach, 1987; (79) Sigg, 1980; (80) Hamitton and Bulger, 1992; (81) Dunbar, 1980; (82) Dunbar and Dunbar, 1975; (83) Watts, 1991; (84) Stewart and Harcourt, 1987; (85) Kano, 1992; (86) Nishida et al., 1990. 


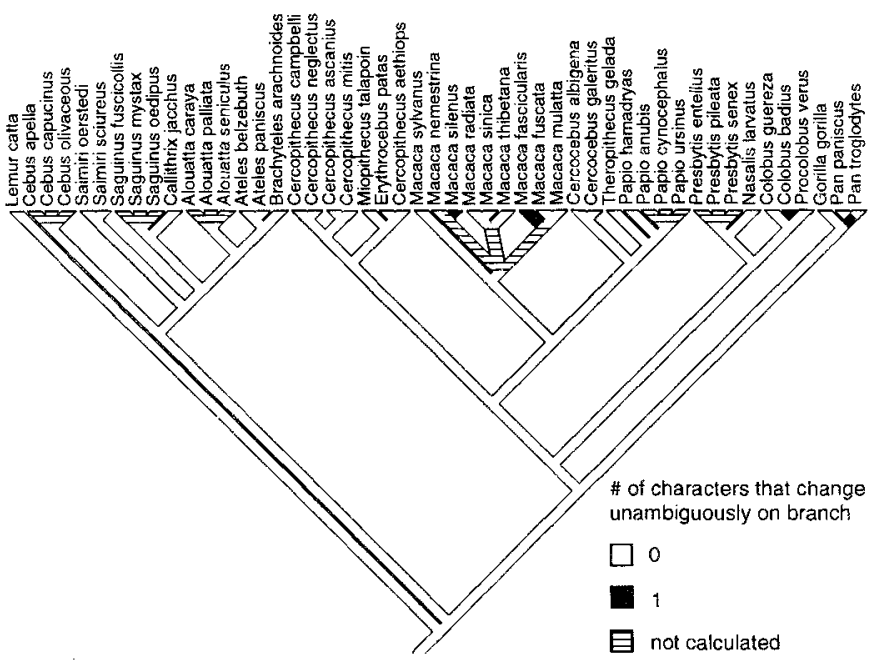

Fig. 2. Neontological-paleontological primate phylogeny (Fig. 1a) showing unambiguous changes in either breeding season duration or female group size.

TABLE III. The Number of Males in Primate Groups*

\begin{tabular}{lcc} 
& \multicolumn{2}{c}{ Male group structure } \\
\cline { 2 - 3 } & Single-male groups & Multimale groups \\
\hline Small female group size, short breeding season & 0 & 0 \\
Large female group size, long breeding season & 0 & 2 \\
\hline
\end{tabular}

*Each cell shows the number of times a particular male group structure evolved under varying conditions of breeding season duration and female group size (cf. Table I). Only those changes that have taken place unambiguously on the phylogeny depicted in Figure 1a are tabulated. See text for further explanation.

pairs comparison using taxa that differ in either breeding season duration (Fig. 4a) or female group size (Fig. 4b). Results reveal no relationship between the number of males in primate groups and the duration of the breeding season. In sharp contrast, male social dispersion appears to be tightly linked to the number of females in a group. Multiple males are frequently found in species with large female groups, while smaller numbers of males associate in groups when there are few females. Replications of the pairwise comparison using species relationships from the molecular phylogeny (Fig. 1b) and alternate neontological-paleontological tree (Fig. 1c) produced results that did not differ from those of our first analysis. Large female groups characterize both blue and red-tail monkeys (Table II), and as a consequence re-classifying these species as multimale results in a stronger relationship between the numbers of males and females in groups (neontological-paleontological tree: Wilcoxon test, $P<0.02, \mathrm{n}=8$; cf. Fig. 4b). Reclassification fails to reveal an association between multimale group structure and breeding season durations (Wilcoxon $P>0.70, \mathrm{n}=7$; cf. Fig. 4a).

Results of Maddison's concentrated changes test accord with the findings of the pairwise contrasts tests. Figure 5a shows that single male groups evolved at least four times in lineages of the molecular phylogeny. Three of these losses are associated with small female groups, while one leading to a Cercopithecus clade is ambiguous (Fig. 5a,b). The probability that these three losses are associated with 
a.

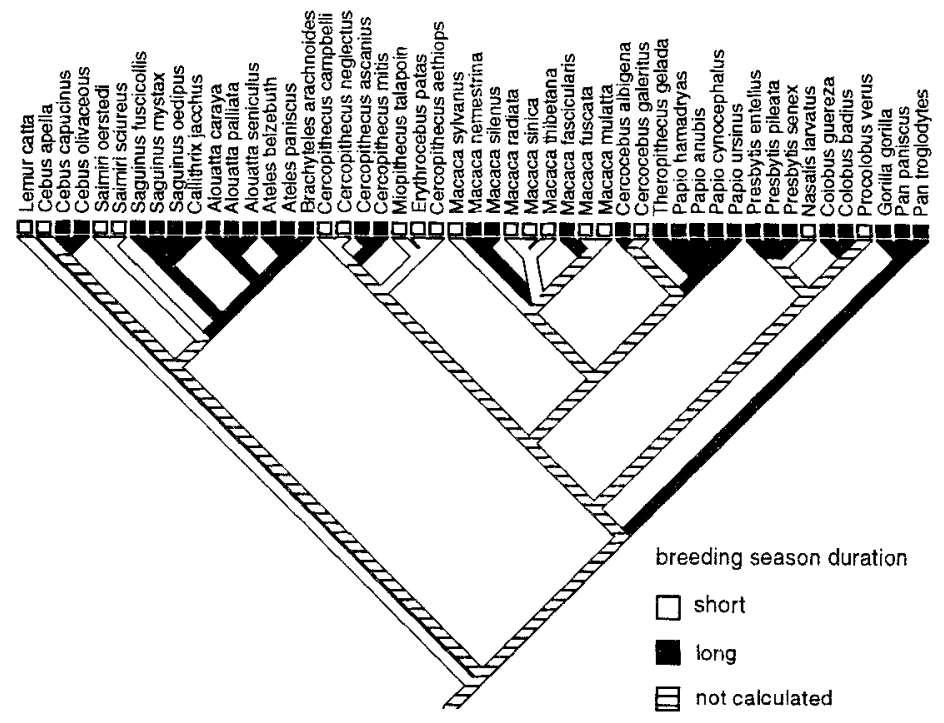

b.

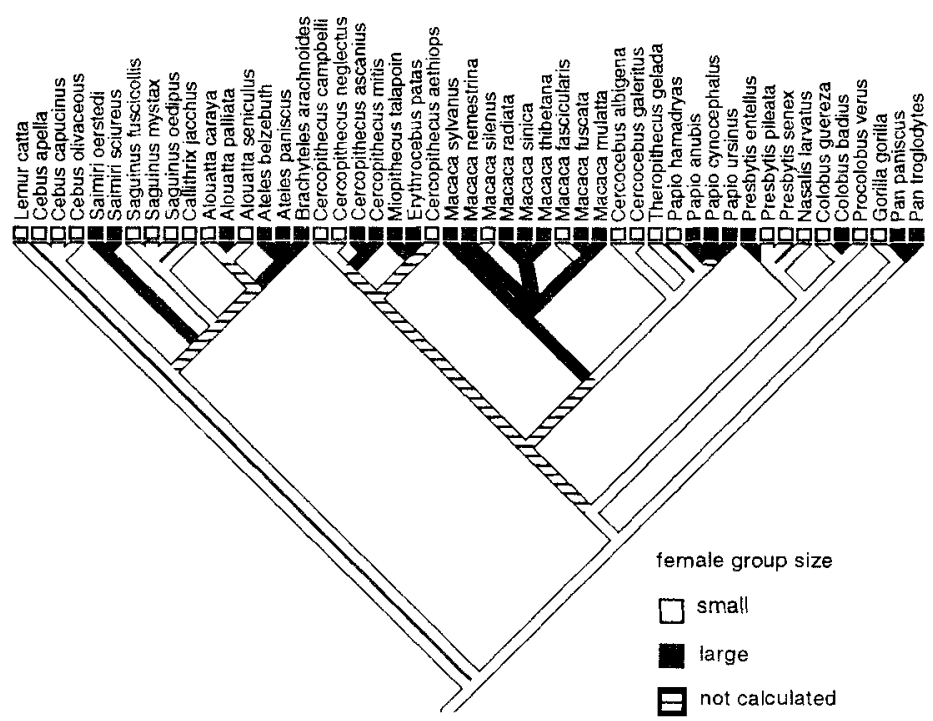

Fig. 3. Neontological-paleontological primate phylogenies (Fig. 1a) showing the distributions of: (a) breeding season durations and (b) female group sizes and their reconstructed ancestral states.

the presence of small groups under the null hypothesis that these losses are randomly distributed across the tree is small $(P \approx 0.06)$. Three of four losses of the multimale state are associated with long breeding seasons and thereby consistent with a prediction of Ridley's hypothesis (Fig. 5a,c). Nonetheless, the probability that these losses are found in the presence of long breeding seasons is high given the observed distribution of short and long breeding seasons on the phylogenetic tree $(P>0.35)$. Replications of Maddison's test using the two neontological-pale- 

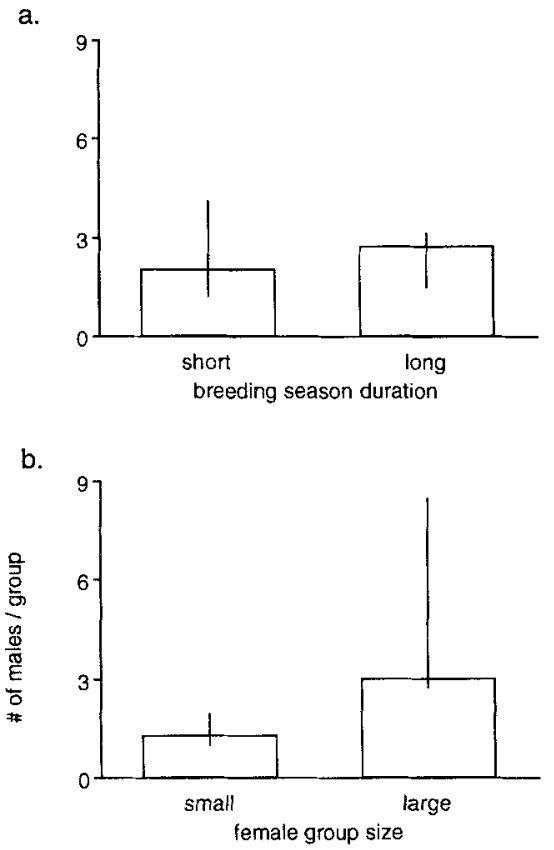

Fig. 4. The number of males in primate groups. a: The number of males as a function of breeding season duration. The length of the mating season did not affect the distribution of males in groups (Wilcoxon matchedpairs, signed-ranks test, two-tailed, $P>0.90, \mathrm{n}=8$ ). b: The number of males as a function of female group size. Significantly more males were found in groups with several females compared with groups with only a few females (Wilcoxon test, $P<0.04, \mathrm{n}=10$ ). Bars represent median values, while vertical lines indicate interquartile intervals.

ontological trees produce results consistent with those from the molecular tree. Results of these analyses are not altered by recategorizing the two cercopithecine species that show male mating season mobility.

\section{DISCUSSION}

Field experiments with fish, birds, and mammals provide empirical support for the longstanding assumption held by many behavioral ecologists that the spatial dispersion of females determines male grouping patterns [Davies \& Lundberg, 1984; Ims, 1988; Warner, 1990]. Since logistical constraints do not permit similar manipulations with nonhuman primates, comparative analyses are required to investigate the association between female and male grouping in this taxon. The preceding analyses represent one of the first quantitative tests of the hypothesis that female group size is a primary determinant of male social dispersion in primates [cf. Andelman, 1986; Dunbar, 1988]. Our results are consistent with this hypothesis, and extend the findings of previous research by indicating that the relationship between female and male grouping persists after removing the potentially confounding effects of phylogeny.

We could not corroborate Ridley's [1986] earlier finding that differences in breeding seasonality affect the number of males found in primate groups. This failure may be due in part to our use of a measure that does not adequately operationalize the independent variable. As Ridley himself noted, breeding seasonality may be a poor estimate of the temporal availability of fertile females. 
a.

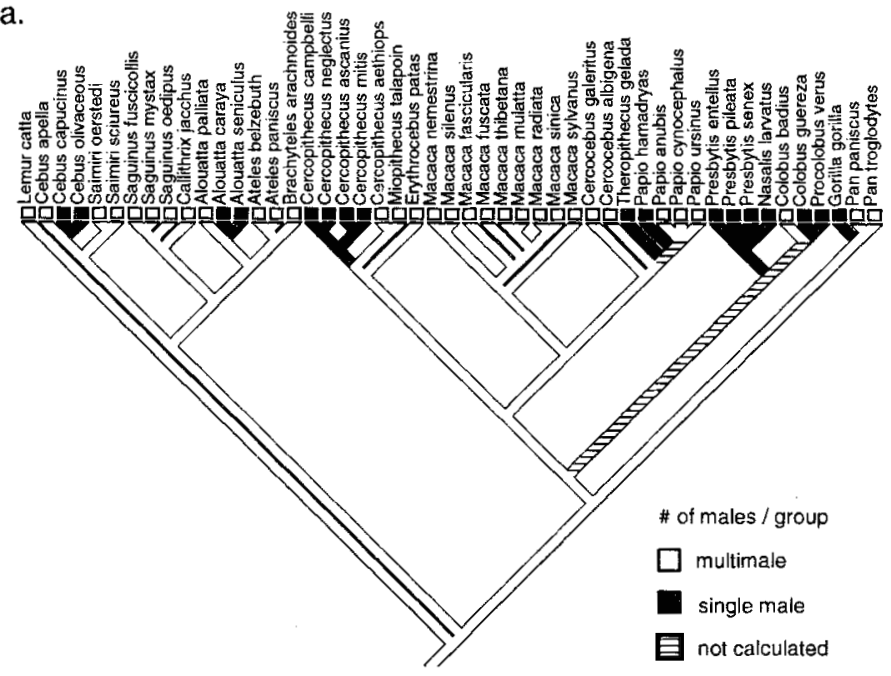

b.

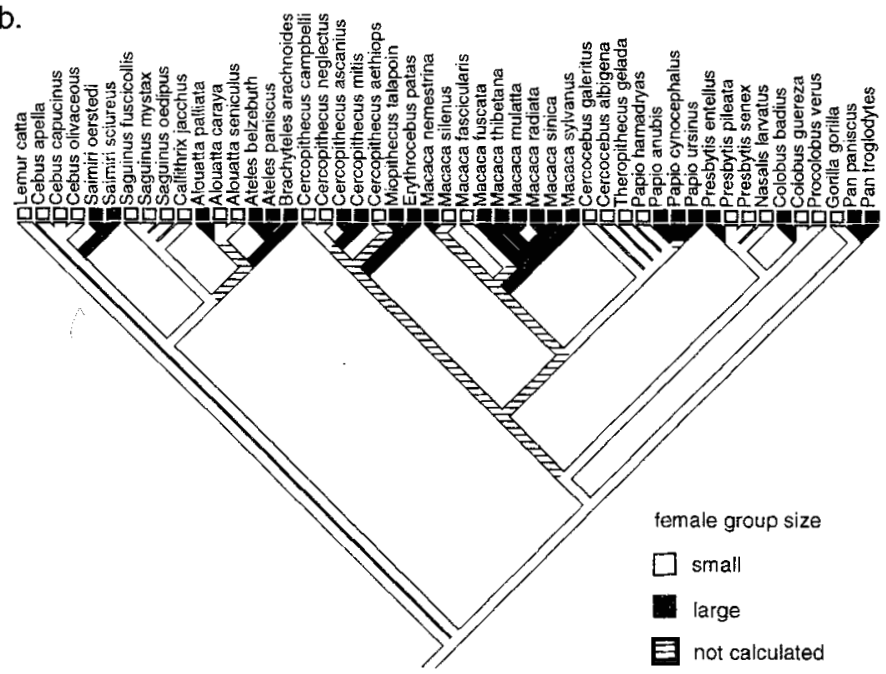

c.

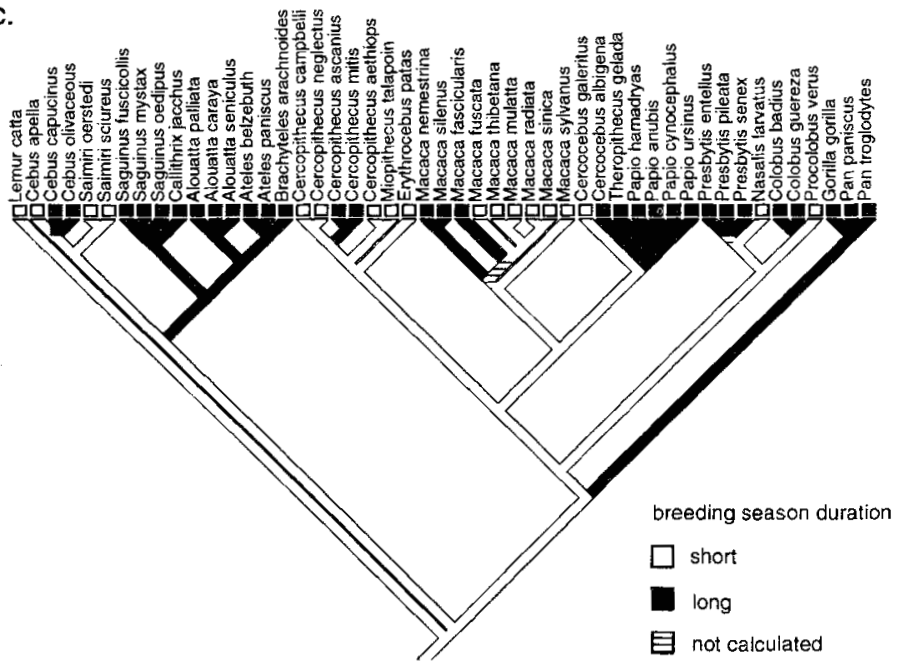

Fig. 5. Molecular primate phylogeny (Fig. 1b) showing the distributions of group composition of males (a) and their reconstructed ancestral states for female group sizes (b) and breeding season durations (c). 


\section{6 / Mitani et al.}

Moreover, since the availability of females varies not only in time but space, a single measure that incorporates the temporal as well as spatial dispersion of reproductively active females promises to be a better predictor of how male primates deploy themselves [cf. Dunbar, 1988].

Although the results presented here support the hypothesis that male mating competition affects the number of males in primate groups, we note multiple exceptions; several species show an association between small female group size and multimale group structure, e.g., see Lemur catta, all Callitrichids, and some $A l$ ouatta, Cebus, Cercopithecus, Cercocebus, and Macaca (Table II). Male group structure in these species is difficult to explain through mating competition and the costs incurred by males who defend females. Instead, the composition of such groups is more likely attributable to the benefits gained by males who tolerate others in groups. Potential benefits include decreasing predation risk [e.g., van Schaik \& Horstermann, 1994], promoting the reproductive success of coresident male kin [e.g., Goldizen, 1990], and gaining the support of male coalition partners against extragroup males [e.g., Wrangham, 1979].

Studies of primates have played an important role in the development of comparative methods currently employed by behavioral ecologists to investigate adaptations [Krebs \& Davies, 1993]. Nonetheless, only scant attention has been paid to the methodological and statistical problems associated with using species as independent data points in these comparative studies. For example in the only other quantitative investigations of the relationship between female and male social dispersion in primates, Andelman [1986] and Dunbar [1988] found positive correlations between female and male group size within and between samples of anthropoid species. Most data points employed in these analyses cannot be considered independent, however, insofar as they share a common evolutionary or group history. Controlling for potentially confounding variables and the effects of phylogeny will remain a central challenge for future comparative studies of adaptation in nonhuman primates [Ridley, 1989; DiFiore \& Rendall, 1994].

While recent advances in comparative methodology provide biologists with an increasingly powerful tool for the study of adaptation [Harvey \& Pagel, 1991], we conclude on a cautionary note. One important limitation of the previous analysis is that it cannot, by its very nature, indicate causality. So for example, our results could equally reflect females adjusting themselves to the spatial distribution of males. Alternatively, the association between female and male group sizes found here may occur if both sexes deployed themselves in an ideal free manner with respect to other resources, such as food [Fretwell, 1972]. Field experiments [e.g., Ims, 1988], where possible, provide the only means to investigate these alternatives.

\section{CONCLUSIONS}

1. Comparative analysis of phylogenetically independent contrasts in breeding season duration and the number of males in primate groups revealed no relationship between these two variables. In contrast, a strong positive association existed between female and male group size.

2. A concentrated changes test for correlated evolution between characters produced results consistent with those from the independent contrasts method. Evolutionary transitions from multimale to single-male groups were associated with small female groups more often than expected by chance. Similar transitions were not significantly associated with long breeding seasons.

3 . These findings are consistent with the hypothesis that the spatial dispersion 
of females determines the grouping patterns of male primates. The length of the mating season appears to have only a minimal effect on male group size.

4. Comparative studies of adaptation in nonhuman primates must control for the potentially confounding effects of hidden variables associated with phylogeny.

\section{ACKNOWLEDGMENTS}

Several colleagues provided advice and access to unpublished data; we thank C. Yeager, P. Waser, J. Wahome, D. Sprague, M. Small, C. van Schaik, L. Rose, S. Perry, J. Oates, C. Janson, P. Garber, L. Fedigan, W. Dittus, L. Digby, M. Cords, J. Chism, S. Boinski, and J. Altmann. We are grateful to D. Cheney, J. Pepper, D. Rendall, A. Richards, C. Sims-Parr, P. Waser, and two anonymous reviewers for comments on the manuscript, and members of Anthropology 668/Psychology 630 during the fall term 1993 for providing the initial impetus to undertake this analysis. Research was supported by a NSF Presidential Faculty Fellows Award to J.C.M.

\section{REFERENCES}

Altmann, J. Primate males go where the females are. ANIMAL BEHAVIOUR 39: 193-195, 1990.

Altmann, J.; Hausfater, G.; Altmann, S. Demography of Amboseli baboons. AMERICAN JOURNAL OF PRIMATOLOGY 8:113-125, 1985.

Altmann, J.; Hausfater, G.; Altmann, S. Determinants of reproductive success in savanna baboons, Papio cynocephalus. Pp. 403-418 in REPRODUCTIVE SUCCESS. T. Clutton-Brock, ed. Chicago, University of Chicago Press, 1988.

Andelman, S. Ecological and social determinants of cercopithecine mating patterns. Pp. 201-216 in ECOLOGICAL ASPECTS OF SOCIAL EVOLUTION. D. Rubenstein; R. Wrangham, eds. Princeton, Princeton University Press, 1986.

Berenstain, L.; Wade, T. Intrasexual selection and male mating strategies in baboons and macaques. INTERNATIONAL JOURNAL OF PRIMATOLOGY 4:201-235, 1983.

Boinski, S. Birth synchrony in squirrel monkeys. BEHAVIORAL ECOLOGY AND SOCIOBIOLOGY 21:393-400, 1987a.

Boinski, S. Mating patterns in squirrel monkeys (Saimiri oerstedi). BEHAVIORAL ECOLOGY AND SOCIOBIOLOGY 21:1321, $1987 \mathrm{~b}$.

Borries, C.; Sommer, V.; Srivastava, A. Dominance, age, and reproductive success in free-ranging female hanuman langurs. INTERNATIONAL JOURNAL OF PRIMATOLOGY 12:231-257, 1991.

Bourlière, F.; Bertrand, M.; Hunkeler, C. L'ecologie de la mone de lowe (Cercopithecus campbelli lowei) en Côte d'Ivoire. TERRE ET VIE 116:135-163, 1969.

Bradbury, J.; Vehrencamp, S. Social organization and foraging in emballonurid

bats. III. Mating systems. BEHAVIORAL ECOLOGY AND SOCIOBIOLOGY 2:1-17, 1977.

Burt, A. Comparative methods using phylogenetically independent contrasts. OXFORD SURVEYS IN EVOLUTIONARY BIOLOGY 6:33-53, 1989.

Caldecott, J. AN ECOLOGICAL AND BEHAVIOURAL STUDY OF THE PIG. TAILED MACAQUE. Basel, Karger, 1986

Cartmill, M.; Yoder, A. Molecules and morphology in primate systematics: An introduction. AMERICAN JOURNAL OF PHYSICAL ANTHROPOLOGY 94:1, 1994. Cheney, D.; Seyfarth, R. The influence of intergroup competition on the survival and reproduction of female vervet monkeys. BEHAVIORAL ECOLOGY AND SOCIOBIOLOGY 21:375-386, 1987.

Cheney, D.; Seyfarth, R.; Andelman, S.; Lee, $P$. Reproductive success in vervet monkeys. Pp. 384-402 in REPRODUCTIVE SUCCESS. T. Clutton-Brock, ed. Chicago, University of Chicago Press, 1988.

Chism, J.; Rowell, T. Mating and residence patterns of male patas monkeys. ETHOLOGY 72:31-39, 1986.

Clarke, M.; Glander, K. Female reproductive success in a group of free-ranging howling monkeys (Alouatta palliata) in Costa Rica. Pp. 111-126 in FEMALE PRIMATES: STUDIES BY WOMEN PRIMATOLOGISTS. M. Small, ed. New York, Alan R. Liss, Inc., 1984.

Clutton-Brock, T. Mammalian mating systems. PROCEEDINGS OF THE ZOOLOGICAL SOCIETY OF LONDON 236:339$372,1989$.

Clutton-Brock, T.; Harvey, P. Evolutionary rules and primate societies. Pp. 195-237 in GROWING POINTS IN ETHOLOGY. P. 
Bateson; R. Hinde, eds. Cambridge, Cambridge University Press, 1976.

Clutton-Brock, T.; Harvey, P.; Rudder, B. Sexual dimorphism, socionomic sex ratio, and body weight in primates. NATURE 269:797-800, 1977.

Cords, M. Mating patterns and social structure in redtail monkeys (Cercopithecus ascanius). ZEITSCHRIFT FUR TIERPSYCHOLOGIE 64:313-329, 1984.

Cords, M.; Mitchell, B.; Tsingalia, H.; Rowell, T. Promiscuous mating among blue monkeys in the Kakamega Forest, Kenya. ETHOLOGY 72:214-226, 1986.

Crockett, C.; Rudran, R. Red howler monkey birth data. I. Seasonal variation. AMERICAN JOURNAL OF PRIMATOLOGY 13: 347-368, 1987.

Cronin, J.; Sarich, V. Molecular systematics of the New World monkeys. JOURNAL OF HUMAN EVOLUTION 4:357-375, 1975.

Cronin, J.; Sarich, V. Marmoset evolution: The molecular evidence. PRIMATE MEDICINE 10:12-19, 1978.

Cronin, J.; Cann, R.; Sarich, V. Molecular evolution and systematics of the genus Macaca. Pp. 31-51 in THE MACAQUES: STUDIES IN ECOLOGY, BEHAVIOR, AND EVOLUTION. D. Lindburg, ed. New York, van Nostrand Reinhold Co., 1980.

Crook, J. The socio-ecology of primates. Pp. 103-166 in SOCIAL BEHAVIOUR IN BIRDS AND MAMMALS. J. Crook, ed. London, Academic Press, 1970.

Crook, J.; Gartlan, S. Evolution of primate societies. NATURE 210:1200-1203, 1966.

Davies, N.; Lundberg, A. Food distribution and a variable mating system in the dunnock Prunella modularis. JOURNAL OF ANIMAL ECOLOGY 53:895-912, 1984.

Dawson, G. Composition and stability of social groups of the tamarin, Saguinus oedipus geoffroyi in Panama: Ecological and behavioral implications. Pp. 23-37 in THE BIOLOGY AND CONSERVATION OF THE CALLITRICHIDAE. D. Kleiman, ed. Washington, DC, Smithsonian Institution Press, 1978.

Dawson, G.; Dukelow, W.R. Reproductive characteristics of free-ranging Panamanian tamarins (Saguinus oedipus geoffroyi). JOURNAL OF MEDICAL PRIMATOLOGY 5:266-275, 1976.

Delson, E. Fossil macaques, phyletic relationships and scenario of deployment. Pp. 10-30 in THE MACAQUES: STUDIES IN ECOLOGY, BEHAVIOR, AND EVOLUTION. D. Lindburg, ed. New York, van Nostrand Reinhold Co., 1980.

DiFiore, A.; Rendell, D. Evolution of social organization: A reappraisal for primates by using phylogenetic methods. PROCEED-
INGS OF THE NATIONAL ACADEMY OF SCIENCES 91:9941-9945, 1994.

Digby, L.; Barreto, C. Social organization in a wild population of Callithrix jacchus. I: Group composition and dynamies. FOLIA PRIMATOLOGICA 61:123-134, 1993.

Digby, L.; Ferrari, S. Multiple breeding females in free-ranging groups of Callithrix jacchus. INTERNATIONAL JOURNAL OF PRIMATOLOGY 15:389-397, 1994.

Dittus, W. The social regulation of population density and age-sex distribution in the toque monkey. BEHAVIOUR 63:281322,1977 .

Dunbar, R. Demographic and life history variables of a population of gelada baboons (Theropithecus gelada). JOURNAL OF ANIMAL ECOLOGY 49:485-506, 1980.

Dunbar, R. PRIMATE SOCIAL SYSTEMS. Ithaca, Cornell University Press, 1988.

Dunbar, R.; Dunbar, E. SOCIAL DYNAMICS OF GELADA BABOONS. Basel, Karger, 1975.

Eisenberg, J.; Muckenhirn, N.; Rudran, R. The relation between ecology and social structure in primates. SCIENCE 176:863874, 1972.

Emlen, S.; Oring, L. Ecology, sexual selection and the evolution of mating systems. SCIENCE 197:215-223, 1977.

Fedigan, L. Sex differences and intersexual relations in adult white-faced capuchins, Cebus capucinus. INTERNATIONAL JOURNAL OF PRIMATOLOGY 14:853-877, 1993.

Felsenstein, J. Phylogenies and the comparative method. AMERICAN NATURALIST 125:1-15, 1985.

Fitch, W. Toward defining the course of evolution: Minimal change for a specific tree topology. SYSTEMATIC ZOOLOGY 20: 406-416, 1971

Ford, S. Systematics of the New World Monkeys. Pp. 73-135 in COMPARATIVE PRIMATE BIOLOGY. VOLUME 1. SYSTEMATICS, EVOLUTION, AND ANATOMY. D. Swindler; J. Erwin, eds. New York, Alan R. Liss, Inc., 1986.

Fretwell, S. POPULATIONS IN A SEASONAL ENVIRONMENT. Princeton, Princeton University Press, 1972.

Garber, P.; Encarnación, F.; Moya, L.; Pruetz, J. Demographic and reproductive patterns in moustached tamarin monkeys (Saguinus mystax): Implications for reconstructing platyrrhine mating systems. AMERICAN JOURNAL OF PRIMATOLOGY 29:235-254, 1993.

Gautier, J.P. Interspecific affinities among guenons as deduced from vocalizations. Pp. 194-226 in A PRIMATE RADIATION: EVOLUTIONARY BIOLOGY OF THE AFRICAN GUENONS. A. Gautier-Hion; 
F. Bourliere; J.P. Gautier; J. Kingdon, eds. Cambridge, Cambridge University Press, 1988.

Gautier-Hion, A. L'organisation sociale d'une bande de talapoins (Miopithecus tal apoin) dans le nord-est du Gabon. FOLIA PRIMATOLOGICA 12:116-141, 1970.

Glander, K. Reproduction and population growth in free-ranging mantled howling monkeys. AMERICAN JOURNAL OF PRIMATOLOGY 53:25-36, 1980.

Goldizen, A. Social relationships in a cooperatively polyandrous group of tamarins (Saguinus fuscicollis). BEHAVIORAL ECOLOGY AND SOCIOBIOLOGY 24:7989, 1989.

Goldizen, A. A comparative perspective on the evolution of tamarin and marmoset social systems. INTERNATIONAL JOURNAL OF PRIMATOLOGY 11:6383, 1990.

Goldizen, A.; Terborgh, J.; Cornejo, F.; Porras, D.; Evans, R. Seasonal food shortage, weight loss, and the timing of births in saddle-back tamarins (Saguinus fuscicollis). JOURNAL OF ANIMAL ECOLOGY 57: 893-901, 1988.

Hamilton, W.; Bulger, J. Facultative expression of behavioral differences between onemale and multimale savanna baboon groups. AMERICAN JOURNAL OF PRIMATOLOGY 28:61-71, 1992.

Harcourt, A.; Harvey, P.; Larson, S.; Short, $R$. Testis weight, body weight and breeding systems in primates. NATURE 293:55-57, 1981.

Harvey, P.; Pagel, M. THE COMPARATIVE METHOD IN EVOLUTIONARY BIOL. OGY. Oxford, Oxford University Press, 1991.

Homewood, K. THE ECOLOGY AND BEHAVIOUR OF THE TANA MANGABEY. Ph.D. dissertation. London, University College, 1976.

Hrdy, S.; Whitten, P. Patterning of sexual activity. Pp. $370-384$ in PRIMATE SOCIETIES. B. Smuts; D. Cheney; R. Seyfarth; R. Wrangham; T. Struhsaker, eds. Chicago, University of Chicago Press, 1987.

Ims, R. Spatial clumping of sexually receptive females induces space sharing among male voles. NATURE 335:541-543, 1988.

Isbell, L. Contest and scramble competition: Patterns of female aggression and ranging behavior among primates. BEHAVIORAL ECOLOGY 2:143-155, 1990.

Janson, C. Female choice and mating system of the brown capuchin monkey Cebus apella (Primates: Cebidae). ZEITSCHRIFT FUR TIERPSYCHOLOGIE 65:177-200, 1984.

Janson, C. Food competition in brown capuchin monkeys (Cebus apella): Quantitative effects of group size and tree productivity. BEHAVIOUR 105:53-75, 1988.

Janson, C. Evolutionary ecology of primate social structure. Pp. 95-130 in EVOLUTIONARY ECOLOGY AND HUMAN BEHAVIOR. E. Smith; B. Winterhalder, eds. Hawthorne, NY, Aldine de Gruyter, 1992.

Kano, T. THE LAST APE. Stanford, Stanford University Press, 1992.

Kay, $R$. The phyletic relationships of extant and fossil Pitheciinae (Platyrrhini, Anthropoidea). JOURNAL OF HUMAN EVOLUTION 19:175-208, 1990.

Kinnaird, M.; O'Brien, T. Viable populations for an endangered forest primate, the Tana River crested mangabey (Cercocebus galeritus galeritus). CONSERVATION BIOLOGY 5:203-213, 1991.

Klein, L. Observations on copulation and seasonal reproduction of two species of spider monkeys, Ateles belzebuth and Ateles geoffroyi. FOLIA PRIMATOLOGICA 15: 233-248, 1971.

Klein, L.; Klein, D. Neotropical primates: Aspects of habitat usage, population density, and regional distribution in La Macarena, Columbia. Pp. 70-78 in NEOTROPICAL PRIMATES: FIELD STUDIES AND CONSERVATION. J.R. Thorington; P.G. Heltne, eds. Washington, DC, National Academy of Sciences, 1976.

Krebs, J.; Davies, N. AN INTRODUCTION TO BEHAVIOURAL ECOLOGY. THIRD EDITION. Oxford, Blackwell Scientific Publications, 1993.

Kumar, A.; Kurup, G. Sexual behavior of the lion-tailed macaque, Macaca silenus. Pp. 109-131 in THE LION-TAILED MACAQUE: STATUS AND CONSERVATION. P. Heltne, ed. New York, Alan R. Liss, Inc., 1985.

Kurup, G.; Kumar, A. Time budget and activity patterns of the lion-tailed macaque (Macaca silenus). INTERNATIONAL JOURNAL OF PRIMATOLOGY 14:27-39, 1993.

Lindburg, D. The rhesus monkey in northern India: An ecological and behavioral study. Pp. 2-106 in PRIMATE BEHAVIOR. L. Rosenblum, ed. New York, Academic Press, 1971.

Maddison, W. A method for testing the correlated evolution of two binary characters: Are gains or losses concentrated on certain branches of a phylogenetic tree? EVOLUTION 44:539-557, 1990.

Maddison, W.; Maddison, D. MACCLADE ANALYSIS OF PHYLOGENY AND CHARACTER EVOLUTION. Sunderland, MA, Sinauer, 1992.

Martin, R.; MacLarnon, A. Quantitative comparisons of the skull and teeth in guenons. Pp. 160-183 in A PRIMATE RADI- 
ATION: EVOLUTIONARY BIOLOGY OF THE AFRICAN GUENONS. A. GautierHion; F. Bourliere; J.P. Gautier; J. Kingdon, eds. Cambridge, Cambridge University Press, 1988.

Maruhashi, T. An ecological study of troop fissions of Japanese monkeys (Macaca fuscata yakui) on Yaku Island, Japan. PRIMATES 23:317-337, 1982.

McHenry, $H$. The common ancestor: A study of the postcranium of Pan paniscus, Australopithecus, and other hominoids. Pp. 201-230 in THE PYGMY CHIMPANZEE. R. Sussman, ed. New York, Plenum, 1984. Melnick, D.; Hoelzer, G.; Absher, R.; Ashley, M. mtDNA diversity in Rhesus monkeys reveals overestimates of divergence time and paraphyly with neighboring species. MOLECULAR BIOLOGY AND EVOLUTION 10:282-295, 1993.

Ménard, N.; Vallet, D. Population dynamics of Macaca sylvanus in Algeria: An 8-year study. AMERICAN JOURNAL OF PRIMATOLOGY 30:101-118, 1993

Ménard, N.; Vallet, D.; Gautier-Hion, A. Démographie et reproduction de Macaca sylvanus dans différents habitats en Algérie. FOLIA PRIMATOLOGICA 44:65-81, 1985.

Mitchell, C. THE ECOLOGICAL BASIS FOR FEMALE SOCIAL DOMINANCE: A BEHAVIORAL STUDY OF THE SQUIRREL MONKEY (Saimiri sciureus) IN THE WILD. Ph.D. dissertation. Princeton, Princeton University, 1990.

Møller, A.; Birkhead, T. A pairwise comparative method as illustrated by copulation frequency in birds. AMERICAN NATURALIST 139:644-656, 1992.

Nicolson, N. WEANING AND THE DEVELOPMENT OF INDEPENDENCE IN OLIVE BABOONS. Ph.D. dissertation. Cambridge, Harvard University, 1982.

Nishida, T.; Takasaki, H.; Takahata, Y. Demography and reproductive profiles. Pp. 63-97 in THE CHIMPANZEES OF THE MAHALE MOUNTAINS. T. Nishida, ed. Tokyo, University of Tokyo Press, 1990.

van Noordwijk, M. Sexual behavior of Sumatran long-tailed macaques (Macaca fascicularis). ZEITSCHRIFT FUR TIERPSYCHOLOGIE 70:277-296, 1985.

Oakes, E. Lekking and the evolution of sexual dimorphism in birds: Comparative approaches. AMERICAN NATURALIST 140:665-684, 1992.

Oates, J. The social life of a black-and-white colobus monkey. ZEITSCHRIFT FUR TIERPSYCHOLOGIE 45:1-60, 1977.

Oates, J. The natural history of African colobines. Pp. $75-128$ in COLOBINE MONKEYS: THEIR ECOLOGY, BEHAVIOUR AND EVOLUTION. A.G. Davies;
J.F. Oates, eds. Cambridge, Cambridge University Press, 1994.

Oates, J.; Davies, A.G.; Delson, E. The diversity of living colobines. Pp. 45-73 in COLOBINE MONKEYS: THEIR ECOLOGY, BEHAVIOUR AND EVOLUTION. A.G. Davies; J. Oates, eds. Cambridge, Cambridge University Press, 1994.

Oi, T. Population organization of wild pigtailed macaques (Macaca nemestrina nemestrina) in West Sumatra. PRIMATES 31: 15-31, 1990.

Ridley, $M$. The number of males in a primate troop. ANIMAL BEHAVIOUR 34:1848$1858,1986$.

Ridley, $M$. Why not to use species in comparative tests. JOURNAL OF THEORETICAL BIOLOGY 136:361-364, 1989.

Robinson, J. Demography and group structure in wedge-capped capuchin monkeys, Cebus olivaceus. BEHAVIOUR 104:202231, 1988.

Rowell, T. Beyond the one-male group. BEHAVIOUR 104:189-201, 1988.

Rudran, $R$. The reproductive cycles of two subspecies of purple-faced langurs (Presbytis senex) with relation to environmental factors. FOLIA PRIMATOLOGICA 19:41$60,1973 \mathrm{a}$.

Rudran, R. Adult male replacement in onemale troops of purple-faced langurs (Presbytis senex senex) and its effect on population structure. FOLIA PRIMATOLOGICA 19:166-192, 1973b.

Rudran, R. The demography and social mobility of a red howler (Alouatta seniculus) population in Venezuela. Pp. 107-126 in VERTEBRATE ECOLOGY IN THE NORTHERN NEOTROPICS. J. Eisenberg, ed. Washington, DC, Smithsonian Institution Press, 1979.

Rumiz, D. Alouatta caraya: Population density and demography in Northern Argentina. AMERICAN JOURNAL OF PRIMATOLOGY 21:279-294, 1990.

Ruvolo, M. Genetic evolution in the African guenons. Pp. 127-139 in A PRIMATE RADIATION: EVOLUTIONARY BIOLOGY OF THE AFRICAN GUENONS. A. Gautier-Hion; F. Bourliere; J.P. Gautier; J. Kingdon, eds. Cambridge, Cambridge University Press, 1988.

Ruvolo, M.; Pan, D.; Zehr, S.; Goldberg, T.; Disotell, T.; von Dornum, M. Gene trees and hominoid phylogeny. PROCEEDINGS OF THE NATIONAL ACADEMY OF SCIENCES 91:8900-8904, 1994.

Sauther, M. Reproductive behavior of freeranging Lemur catta at Beza Mahafaly Special Reserve, Madagascar. AMERICAN JOURNAL OF PRIMATOLOGY 84:463$478,1991$.

van Schaik, C. Why are diurnal primates 
living in groups? BEHAVIOUR 87:120 $144,1983$.

van Schaik, C. The ecology of social relationships amongst female primates. Pp. 195218 in COMPARATIVE SOCIOECOLOGY. V. Standen; R. Foley, eds. Oxford, Blackwell Scientific Publications, 1989.

van Schaik, C.; Horstermann, M. Predation risk and the number of adult males in a primate group: A comparative test. BEHAVIORAL ECOLOGY AND SOCIOBIOLOGY 35:261-272, 1994.

van Schaik, C.; van Noordwijk, M. Interannual variability in fruit abundance and the reproductive seasonality in Sumatran long-tailed macaques (Macaca fascicularis). PROCEEDINGS OF THE ZOOLOGICAL SOCIETY OF LONDON 206:533$549,1985$.

Siegel, S.; Castellan, N.J. NONPARAMETRIC STATISTICS FOR THE BEHAVIORAL SCIENCES. New York, McGrawHill, 1988.

Sigg, H. Differentiation of female positions in hamadryas one-male-units. ZEITSCHRIFT FUR TIERPSYCHOLOGIE 53: 265-302, 1980.

Smuts, B. SEX AND FRIENDSHIP IN BABOONS. Hawthorne, NY, Aldine de Gruyter, 1985.

Smuts, B.; Cheney, D.; Seyfarth, R.; Wrangham, R.; Struhsaker, R., eds. PRIMATE SOCIETIES. Chicago, University of Chicago Press, 1987.

Sommer, V.; Rajpurohit, L. Male reproductive success in harem troops of Hanuman langurs (Presbytis entellus). INTERNATIONAL JOURNAL OF PRIMATOLOGY 10:293-317, 1989.

Stammbach, E. Desert, forest and montane baboons: Multilevel-societies. Pp. 112-120 in PRIMATE SOCIETIES. B. Smuts; D. Cheney; R. Seyfarth; R. Wrangham; T. Struhsaker, eds. Chicago, Chicago University Press, 1987.

Stanford, C. THE CAPPED LANGUR IN BANGLADESH. Basel, Karger, 1991a.

Stanford, C. Social dynamics of intergroup encounters in the capped langur (Presbytis pileata). AMERICAN JOURNAL OF' PRIMATOLOGY 25:35-47, 1991b.

Stewart, K.; Harcourt, A. Gorillas: Variation in female relationships. Pp. 155-164 in PRIMATE SOCIETIES. B. Smuts; D. Cheney; R. Seyfarth; R. Wrangham; T. Struhsaker, eds. Chicago, University of Chicago Press, 1987.

Strasser, E.; Delson, E. Cladistic analysis of cercopithecid relationships. JOURNAL OF HUMAN EVOLUTION 16:81-99, 1987.

Strier, K.; Ziegler, T. Insights into ovarian function in wild Muriqui monkeys (Brachyteles arachnoides). AMERICAN
JOURNAL OF PRIMATOLOGY 32:31-40, 1994.

Strier, K.; Mendes, F.; Rimoli, J.; Rimoli, A. Demography and social structure of one group of muriquis (Brachyteles arachnoides). INTERNATIONAL JOURNAL OF PRIMATOLOGY 14:513-526, 1993.

Struhsaker, T. THE RED COLOBUS MONKEY. Chicago, University of Chicago Press, 1975.

Struhsaker, T. Male tenure, multi-male influxes, and reproductive success in redtail monkeys (Cercopithecus ascanius). Pp. 340-363 in A PRIMATE RADIATION EVOLUTIONARY BIOLOGY OF THE AFRICAN GUENONS. A. Gautier-Hion; F. Bourliere; J. Gautier; J. Kingdon, eds. Cambridge, Cambridge University Press, 1988.

Struhsaker, T.; Leland, L. Colobines: Infanticide by adult males. Pp. 83-97 in PRIMATE SOCIETIES. B. Smuts; D. Cheney; R. Seyfarth; R. Wrangham; T. Struhsaker, eds. Chicago, Chicago University Press, 1987.

Sugiyama, Y. Characteristics of the social life of bonnet macaques (Macaca radiata). PRIMATES 12:247-266, 1971.

Sussman, R. Demography and social organization of free-ranging Lemur catta in the Beza Mahafaly Reserve, Madagascar. AMERICAN JOURNAL OF PRIMATOLOGY 84:43-58, 1991.

Symington, M.M. Demography, ranging patterns, and activity budgets of black spider monkeys (Ateles paniscus chamek) in the Manu National Park, Peru. AMERICAN JOURNAL OF PRIMATOLOGY 15:4567, 1988.

Takahata, Y.; Sprague, D.; Suzuki, S.; Okayasu, N. Female competition, co-existence, and the mating structure of wild Japanese macaques: Recent advances in the ecological and sociological studies of wild Japanese macaques in Yaku Island. In ANIMAL SOCIETIES: INDIVIDUALS, INTERACTIONS, AND ORGANIZATION. P. Jarman; A. Rossiter, eds. Kyoto, Kyoto University Press, in press.

Terborgh, J. FIVE NEW WORLD PRIMATES: A STUDY IN COMPARATIVE ECOLOGY. Princeton, Princeton University Press, 1983.

Terborgh, J.; Janson, C. The socioecology of primate groups. ANNUAL REVIEW OF ECOLOGY AND SYSTEMATICS 17:111135, 1986.

Trivers, R. Parental investment and sexual selection. Pp. 136-179 in SEXUAL SELECTION AND THE DESCEN'T OF MAN. B. Campbell, ed. Chicago, Aldine, 1972.

Tsingalia, H.; Rowell, T. The behaviour of 


\section{2 / Mitani et al.}

adult male blue monkeys. ZEITSCHRIFT FUR TIERPSYCHOLOGIE 64:253-268, 1984.

Wahome, J.; Rowell, T.; Tsingalia, H. The natural history of de Brazza's monkey in KenYa. INTERNATIONAL JOURNAL OF PRIMATOLOGY 14:445-466, 1993.

Warner, R. Male versus female influences on mating site determination in a coral reef fish. ANIMAL BEHAVIOUR 39:540$548,1990$.

Waser, P. Monthly variation in feeding and activity patterns of the mangabey, Cercocebus albigena (Lyddeker). EAST AFRICAN WILDLIFE JOURNAL 13:249-263, 1975.

Watts, D. Mountain gorilla reproduction and sexual behavior. AMERICAN JOURNAL OF PRIMATOLOGY 24:211-225, 1991.

Wrangham, R. On the evolution of ape social systems. SOCIAL SCIENCE INFORMATION 18:335-368, 1979.
Wrangham, R. An ecological model of female-bonded primate groups. BEHAVIOUR 75:262-300, 1980.

Wrangham, R. Evolution of social structure. Pp. 282-296 in PRIMATE SOCIETIES. B. Smuts; D. Cheney; R. Seyfarth; R. Wrangham; T. Struhsaker, eds. Chicago, University of Chicago Press, 1987.

Yeager, C. Proboscis monkey (Nasalis larvatus) social organization: Group structure. AMERICAN JOURNAL OF PRIMATOLOGY 20:95-106, 1990.

Zhao, Q.; Deng, Z. Macaca thibetana at Mt. Emei, China: III. Group composition. AMERICAN JOURNAL OF PRIMATOLOGY 16:269-273, 1988a.

Zhao, Q.; Deng, Z. Macaca thibetana at Mt. Emei, China: II. birth seasonality. AMERICAN JOURNAL OF PRIMATOLOGY 16 : 261-268, 1988b. 